\title{
Rahmah El-Yunisiyah's Dedication in Islamic Education for Women in Indonesia
}

\author{
Rhoni Rodin ${ }^{1 *}$, Miftahul Huda ${ }^{2}$ \\ 1,2 Institut Agama Islam Negeri Bengkulu, Indonesia
}

Corresponding Author: @rhoni.rodin@iaincurup.ac.id*

\section{ABSTRACT}

The history of Islamic education in Indonesia, apart from having a traditional character, not all women have had the opportunity to pursue education. The society paradigm considers that women are only weak creatures who do not need higher education. This has an impact on the role of women only in the domestic sphere, which does not have a broad role in the public sphere in society. Such social conditions moved the

ARTICLE INFO

Article history:

Received

October 20, 2020

Revised

November 06, 2020

Accepted

November 15, 2020

How to cite

Journal Homepage This is an open access article under the CC BY SA license heart of a reformer figure in Islamic education from West Sumatra, named Rahmah el-Yunusiyah. The purpose of this study was to determine the sacrifice and struggle of Rahmah el-Yunusiah in the field of education and Rahmah el-Yunusiyah's views on the essence of Islamic religious education. She is the first female Islamic education figure to pay attention to the importance of education for women. She realizes that education is the main means to improve the position of women in the global life order. In this study using a qualitative approach. The method used is a research library. The data analysis technique used is content analysis. The result of this research shows that Rahmah el-Yunusiyah's dedication in Islamic education for women is that she founded the Diniyah school Puteri. According to him, religious education (Islam) according to him is the basis for the formation of human character, and becomes the essence for other activities.

Keywords: Rahmah el-yunusiyah, Islamic education, Dedication a Good Women

Rodin, R., \& Huda, M., (2020). Rahmah El-Yunsiyah's Dedication in Islamic Education for Women in Indonesia (International Journal on Advanced Science, Education, and Religion), 3(3). 96-106. https://doi.org/10.33648/ijoaser.v3i3.82 https://ojs.staialfurqan.ac.id/IJoASER/

https://creativecommons.org/licenses/by-sa/4.0/

\section{INTRODUCTION}

In fact, the educational process is a process to develop the potential of students who have certain abilities and skills, it's just that it needs to be understood together that basically it is not easy to be able to accommodate the needs of each student appropriately in the educational process, but it must also be an understanding that every student must treated fairly in the educational process, including without discrimination against socio-economic background, culture, language and gender (Masyitoh et al., 2020). The history of great men is the history of women. They are born and educated by a woman. Some of the women are scholars. The clergy of women and their role as teachers of male scholars have existed since the beginning of Islamic history. Some of the women who became teachers of male friends, among others: 
Aisyah bint Abu Bakr. He is referred to as "A 'lam al-Nas wa Afqah al-Nas wa Ahsan al-Nas Ra'yan fii al-'Ammah" (the smartest, most faqih, and best of all people). AlDzahabi in "Siyar A 'lam al-Nubala" (biographies of intelligent scholars) says: "no less than 160 male friends recite the Koran to Siti Aisyah". Some hadith scholars say that Siti Aisyah's students were 299: 67 girls and 232 boys. Umm Salamah bint Abi Umayyah taught 101 people: 23 women and 78 men. Hafsyah binti Umar taught 22 students: 3 girls and 17 boys. Hujaimiyah al-Washabiyyah taught 22 male students. Ramlaha bint Abi Sufyan taught 21 students: 3 girls and 18 boys. Fatimah binti Qais taught 11 male students (Muhammad al-Habasy, 2018).

Historical facts in the early days of Islamic civilization show with certainty that many women became scholars, scholars, and intellectuals with the same capacity and expertise as men, even surpassing them. These facts automatically challenge the assumption that women are less intellectual than men. Islam is here to elevate the status of women, suppress ignorance towards the realization of a just life and advance knowledge for all human beings, both men and women.

In Islam there is no difference between men and women to get education. Because it is clear that studying is obligatory for Muslims. This is confirmed in the hadith of the Prophet narrated by Ibn Abdil Barr:

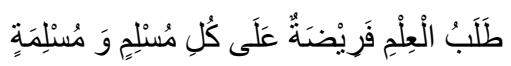

Meaning: "seeking knowledge is mandatory for every male Muslim and female Muslim" (HR. Ibnu Abdil Barr).

From this hadith, it is clear that women are obliged to study, in the sense that women have the same rights as men to pursue education. The importance of education for women has an important role for the progress of religion and nation. It is women who give birth to generations of people who are intelligent, of high quality and of noble character.

The idea of renewal in Islam emerged in the modern period in the 1800s, this period was the period of the awakening of the Muslim community (Harun Nasution, 2019; Mukhlis, 2020)). The growth and development of madrasas in Indonesia cannot be separated from the growth and development of ideas for renewal of thought among Muslims. At the beginning of the 20th century, there were several changes in the thinking of Muslims in Indonesia by incorporating several ideas for reform. The emergence of these renewal ideas has several driving factors (Kareel A Steen Brink, 1994). First, there is a tendency for Muslims to return to the Koran and Hadith. This tendency is used as a reference for assessing religious and cultural habits that exist in society. The main idea of wanting to return to the Koran and Hadith is in an effort to reject imitation. Second, the emergence of a push for national resistance against the Dutch colonial rulers. Third, the strong efforts of Muslims to strengthen their organization in the social and economic fields, for the benefit of themselves and society. Fourth, further encouragement from the renewal of Islamic education. Because at that time quite a number of Islamic individuals and organizations were dissatisfied with traditional methods of studying the Koran and religious studies. Islamic individuals and organizations in the early 20th century tried to improve Islamic education both in terms of method and content.

In historical records, every thought will develop in society if it is supported by several factors (Muhammad Azhar, 1996), including: first, the character of the person who brings the idea; second, the strength of the ideas developed is rational and 
argumentative; third, the idea is in accordance with the times; fourth, literature containing widely marketed ideas; fifth, the student who brings the idea studied with him a lot, which means helping to develop the idea; sixth, the ideas that are raised are new and actual so that they are interesting to be used as study material; seventh, the development of an idea cannot be separated from scientific forums such as seminars, studies, and other scientific studies. It is also very influential in the modern era for the transformation of an idea with the publication media and mass media. Renewal, as Harun Nasution said, is the same as modernization (Harun Nasution, 2019). Usually a historical process, renewal in Islam is directed at the efforts of awakening the Muslim community in the process of orthodoxy of Islamic teaching (Dudung Abdurrahman, 2000; Novianti, 2020). The reformers see that the renewal movement in the field of education is very urgent with the condition of society (Deliar Noer, 1996). Another aspect is the arrival of foreign nations who colonized Indonesia, namely the Netherlands by establishing secular-based schools. This has resulted in a dualistic education system, between government schools and educational institutions established by Muslims. Thus, in understanding and explaining this renewal process, there are several concepts that are used as the basis for theory and thinking framework. First, the theory of challenge and response (challenge and response) expressed by Arnold J. Toynbee. According to Arnold, every historical movement arises because of an incentive to react by creating responses and making changes (Sidi Gazalba, 1996). Second, feminism theory, which is related to education, namely poststructuralist theory and postmodernism (Gadis Arivia, 2002; Ni'am,2015). This theory basically criticizes and deconstructs philosophy in favor of foundationalism and absolutism, in which education that is very male-centered is not questioned or is considered natural.

As previous studies that discuss the same character in this study, for example like, Rohmatun Lukluk Isnaini the research entitled Women and dedication Ulama in Islamic Education (Assessing thought rahmah el-Yunusiyah) (Rohmatun Lukluk Isnaini, 2016). In his conclusion, he said that women can also take part in the public sphere and their social environment without leaving their main duties as wives or mothers. Their work can also be used as a basis for women to have the same opportunities as men and even to become leaders. Likewise, Prilia Wulandari's research in her research entitled Women in the Public Sector in an Islamic Perspective (Rahmah el-Yunusiyah's Progressive View on Leadership as a Ulama and Pioneer of Indonesian Muslim Women's Education) (Prilia Wulandari, 2017). In her research, she concluded, first, Rahmah el-Yunusiyah was a woman who never gave up. Second, Rahmah el-Yunusiyah was the first woman to establish a special school for women. Third, Rahmah el-Yunusiyah was awarded the title (honoris causa) "shaykh" from the al-Azhar University of Egypt for her attention to advancing the education of her people. Fourth, the style of struggle is religious. Likewise, research conducted by Asni Furoidah, entitled Figure of Islamic Education for Women, Rahmah el-Yunusiyah (Asni Furoidah, 2019). In his conclusion, he explained that Rahmah was the main driver of progress for women in West Sumatra at that time. Rahmah el-Yunusiyah with her daughter Diniyah institution have based her struggle as a symbol of Islamic women among female fighters who are struggling in the world of education in Indonesia.

In the literature that the author mentioned above, the writer sees that there is no thought of Islamic education for women. Rahmah el-Yunusiyah regarding the curriculum of Islamic religious education, why did Rahmah el-Yunusiyah establish a special school for women (diniyah school putri)? as well as how the socio-political 
context is the background for his thinking. At most, it only reveals who Rahmah elYunusiyah is and the institution he founded. Even then, the authors see that most of them only tend to provide explanations about their leadership as scholars.

Based on the literature review, the authors consider that this research has a significant newness and contribution of knowledge in Islamic education and therefore it is academically feasible to do so.

\section{METHOD}

In this study, researchers used research on figures. Study of figures or often referred to as character research or individual life history research is one type of research that uses a qualitative approach (Arief Furchan dan Agus Maimun, 2005). The method used is library research (library research), which is to analyze the contents of the various literature related to research. Qualitative data analysis is an effort made by working with data, organizing data, sorting it into manageable units, synthesizing it, looking for and finding patterns, discovering what is important, what is learned, and deciding what is shared with others (Lexy J. Moleong, 2018; Anggito \& Setiawan, 2018). Furthermore, the data analysis technique used is content analysis. This technique is used to analyze the meaning contained in Rahmah el-Yunusiyah's thoughts based on the content contained in Rahmah el-Yunusiyah's thoughts, then grouping them with the stages of identification, classification, categorization, then interpretation and narrative description.

\section{RESULT AND DISCUSSION \\ Life History of Rahmah El-Yunusiah}

This female reformer figure in Islamic education was born in Padang Panjang, West Sumatra, 29 December 1900 and died in Padang Panjang, West Sumatra, on February 29, 1969. He is the youngest of four children of the pair Shaykh Muhammad Yunus and Rafi'ah. His father was a scholar who was an expert in astronomy and his grandfather, Shaykh Imaduddin, was a well-known scholar in Minangkabau, a leader of the Naqsyabandiyah Tarekat (Tim, 1999). Rahmah is the founder of the first female Diniyah school (madrasah diniyah) in Indonesia which is located in Padang Panjang (West Sumatra), which is the first women's college in Indonesia. He was also the pioneer of the establishment of the People's Security Army (TKR) in West Sumatra.

His educational history began with studying with his father, but lasted only briefly because his father died. Then he continued learning to read and write to his older siblings, namely Zainudin Labai el-Yunusy and M. Rasyad. Zainudin Labai is a reformer figure in Islamic education in West Sumatra, he is the founder of the diniyah school, Rahmah studied at the school until the third grade. Rahmah did not feel satisfied studying at the school her brother had founded because she could not solve many problems, especially problems regarding women, and then she studied with several scholars. He studied religion with several well-known teachers in Minangkabau, such as H. Abdul Karim Amrullah (Mr. Buya Hamka), Tuanku Mudo Abdul Hamid Hakim, Shaykh Muhammad Jamil Jambek, Syaikh Abdul Latif Rasyidi, and Shaykh Daud Rasyidi (Abuddin Nata, 2005; Pratama \& Zulhijra 2019). Apart from religious knowledge, she also studied midwifery and skills, such as cooking, sewing, and weaving, which would later be taught back to her students at Diniyah school for girls. 


\section{Women's education in the view of Rahmah El-Yunusiyah}

Seeing the situation of women around her who do not get proper education, Rahmah has a mission to provide educational facilities for women. In Rahmah's view, women have an important role in life. Because women are educators of children and someone who prepares the future of children who are the next generation of the nation and religion. Therefore, a woman must have a high intellectual level, and have a good personality and skills in various things.

Realizing the importance of women's education, in 1923 Rahmah and her female friends founded Diniyah School Putri. In 1927, Rahmah experienced a lack of funds to build his college building. He refused the help that was given to him in a subtle and gentle way. He wants to show men that women can do what men can do, even more than that. Rahmah also said diplomatically:

"This suggestion is highly appreciated by the board and teachers, but for the time being, the women (princess) will try to send the thief by themselves to the edge of the land and when the female power is no longer able to save the thief, then with all my heart the teachers and The management will ask for your suggestions now, to you who we think we deserve to give up that hope. "

In the field of education, Rahmah has aspirations, namely that women can get the full opportunity to get an education in accordance with the nature of women. So that it can be practiced in everyday life and become a competent mother educator, who is responsible for religion and nation. With the establishment of the Diniyah Putri school, it is Rahmah's first step in realizing these dreams.

\section{Rahma El-Yunusiyah's dedication to women's education}

The discussion about Rahmah el-Yunusiyah about education for women is very relevant to the two theories presented in the above background, because the efforts to reform education that he pioneered could not be separated from the situation of Islamic education in Minangkabau at that time which was still closed on women's issues, as well as general views. Minangkabau society towards the marginalization of the role of women (Djunaidatul Munawaroh, 2000). In educational institutions other than schools and communities, the family is a more essential educational institution, which affects the condition of the child both psychologically and intellectually. Mother is the supreme teacher in the family. Mother is the main source of education for children. This is in line with the Usulut Tarbiyah wa Ta'lim Juz Tsalis book:

Mother is the first school for her child (Sutrisno Ahmad, 2019).

$$
\text { الام مدرسة الاؤل للولد }
$$

A mother must be a professional. In his hands it depends on the fate of the child. Mothers who know many educational methods are better than those who don't. They can find out the essence of education. Various methods make mothers more flexible in educating their children. Mothers build good relationships during the educational process, so that the values that they want to instill in children are easily absorbed (Saiful Falah, 2014). Education for women is very important, because great children are born to great mothers.

This can be seen from the early 20th century until today we witness new efforts to strengthen the marginalization of women. Inevitably, in the history of Islamic education in Indonesia, apart from having a traditional pattern, not all women have had the opportunity to pursue education. Moreover, the paradigm of society considers that women are only weak creatures who do not need higher education, because 
basically women only become housewives who return to kitchens, wells and mattresses. So it is sufficient for women to only be given basic education and household skills such as cooking, making up and so on so that they are ready to become housewives. This has an impact on the role of women only in the domestic sphere, which does not have a broad role in the public sphere in society. Because they lack access to seize various opportunities in the job market and various other opportunities.

Such social conditions moved the heart of a reformer figure in Islamic education from West Sumatra, named Rahmah el-Yunusiyah. She is the first female Islamic education figure to pay attention to the importance of education for women. She realizes that education is the main means to improve the position of women in the global life order. And at this time, if you look at women who have taken part in the public sector, social environment, and have obtained the same education rights as men, all of this is inseparable from their struggle as a female scholar in Indonesia, Rahmah el-Yunusiyah.

History has recorded that throughout his life Rahmah el-Yunusiyah was dedicated to Islamic education for women in Indonesia (1900 - 1969 AD). Starting from his concern for the fate of women in his era, who did not have equal opportunities to learn between men and women. When he went to school in one class, it was dominated by men and the majority of the teachers were men, because at school he always felt seconded as a woman in his class, especially women as a minority so that he was embarrassed to ask his teachers who were all male. Especially in the subject of fiqh, female students are embarrassed to ask questions. So he was determined and had the idea of establishing an Islamic school for women. Her struggle for women was realized by establishing a special madrasah for women called Madrasah Diniyah Puteri (Diniyyah School Puteri) in Minangkabau land as a renewal of Islamic education for women in Indonesia.

Why did Rahmah el-Yunusiyah establish a female diniyah school / madrasah diniyah daughter? And what is the socio-political context behind its thinking? Rahmah el-Yunusiyah's efforts in the field of Islamic education, especially for women, are motivated by her ideals, namely that she wants women in Indonesia to have and have the same opportunity to study knowledge so that it can be applied in their daily activities. Her educational efforts are directed so that women in Indonesia are independent, responsible and become mothers who are capable of knowledge and morals to give birth and educate the nation's future generations towards the welfare of Indonesia.

The ideals and goals of her education are explained in the purpose of establishing Diniyah school girls. In addition, Rahmah sees problems that are only specific to women and can only be given to women (Deliar Noer, 1996). Rahmah el-Yunusiyah founded Diniyah school girls on November 1, 1923. The first time this school was founded, it had 71 students, the majority of whom came from young housewives. The lessons are given every day for 3 hours at a mosque in Pasar Usang, Padang Panjang, and consist of religion and instrument science lessons. However, in 1924 the school moved to a house near the mosque and began to run classes equipped with chairs, desks and blackboards. The part above this house functioned as a dormitory, in 1925 it was inhabited by about 60 students (Deliar Noer, 1996).

In addition to these efforts, Rahmah made efforts to eradicate illiteracy among older mothers. At first, this teaching and learning activity was attended by approximately 125 students, but then it was stopped because in 1926 there was a very 
great earthquake so that the school was destroyed. So for the time being, Rahmah built a building made of bamboo as a substitute for the class he endured. And in 1927 he went to raise funds in North Sumatra to build a school building permanently, then it was completed in 1928 (Deliar Noer, 1996).

Diniyah school Puteri was affected by the political impact of the independence struggle that was developing at that time. Fortunately, the political impact that entered Puteri's Diniyah school did not develop in such a way that it did not interfere with teaching and learning activities at the school. The political impact came from Permi and not from the communists.

In the 1930s political activity among Islamic teachers in Minangkabau increased. A Puteri Diniyah School teacher, Rasuna Said, began to express her views through the lessons given in class and her talks outside the classroom. According to Rasuna Said, students in addition to being given learning materials should be given insights into political struggle and participation. According to him, a student should be given a variety of knowledge to get involved in the world of movement. Thus the intention is that if necessary, teaching and learning activities and other religious activities must be reduced in order to provide more opportunities for political training (Deliar Noer, 1996).

Rasuna Said's opinion was opposed by Rahmah, as the director and principal of the women's Diniyah School. Rahmah believes that religious studies are more important than any lesson. The reference to Rahmah's opinion is based on the fourth caliph, Ali bin Abi Talib. Rahmah tries to compare the situation of boys and girls, unchanging like a clean piece of paper on which anything can be written. On the basis of this thinking, religious lessons are a basis for assessing all the problems they will face in the future. According to Rahmah, political problems will automatically be recognized by students when they are involved in them after they finish studying at school. During teaching and learning activities students do not need to be involved in political activities. What is important is the Islamic basis they receive in school which will later become the basis for their efforts in political activities. Love for the motherland and political attitudes if based on faith are not easily shaken. On the other hand, any ability in a political movement is used against the interests of Islam if it is not accompanied by faith (Deliar Noer, 1996).

Rahmah's thoughts were followed by his observation that the political leaders of his time in Minangkabau consisted of people who in their youth only received religious lessons at their schools. There are no specific political lessons. By looking at this phenomenon, Rahmah concluded that students do not need to be given lessons that emphasize politics in particular.

Apart from being an educator, Rahmah is also a warrior. He was the person who first raised the red and white flag at his school after hearing the news of the proclamation of Indonesian independence. In 1958 he was active in politics and became a member of the Regional Indonesian National Committee (KNID) of Central Sumatra. And the constituent members represent Masyumi. His very striking role was that he was an initiator in the formation of the People's Security Army (TKR) in West Sumatra on October 2, 1945.

Kartini Padang Panjang whose profile has never been raised but her influence in the world of education is very real. Even Al-Azhar Egypt was inspired by his actions. Last but not least, the elegant clothes with the veil covering the chest (Hijab Syar'i) and the basiba brackets are the hallmarks of students and teachers at Diniyah Padang Panjang schools and Muslim women from Malaysia and Singapore. 
Rahmah el-Yunusiah's concern for women never goes out of style with time. She wants to establish a special university for women with complete facilities and infrastructure. Most of this wish has been fulfilled. It can be seen that when she died, Diniyah School Putri already had a university with one faculty, namely the Dirasah Islamiyah Faculty.

Rahmah elyunusiyah is a person who has a strong stand in instilling a spirit of religion in the educational institutions he founded. Because for him religion is the basis for the formation of human character, and becomes the foundation for other activities, such as political activities. He is also of the opinion that the school he built should be kept away from political practice activities. Because according to him, if the school he founded was involved and involved in practical political activities, this could cause the school to not work and run professionally. He hopes that students who study in his school will study diligently, diligently, and full of enthusiasm. After graduating from school, he will jump into the community according to his interests, talents and expertise, including being allowed to enter the political field.

This finding was so different from previous research, for intsatnce Zulmuqim's research entitled transformation of the Minangkabau Islamic education: the study of education thought of Abdul Karim Amrullah, Abdullah Ahmad, and Rahmah elYunusiah (Zulmuqim, 2015). In his conclusion, he explained that Abdul Karim Amrullah began to transform Islamic education by changing the status of the Iron Bridge Surau into a modern Islamic Madrasah (Madrasah) with a class system known as Sumatra Thawalib. Abdullah Ahmad transformed Islamic education by establishing HIS Adabiyah with a school system, and also including Islamic subjects in the curriculum. Moreover, Rahmah el-Yunusiyah made reforms by building a women's madrasa. Likewise, research from Devi Wahyuni entitled women's leadership policies in Islamic education: a reflection on the leadership of RKY Rahmah el-Yunusiyah in 2017 (Devi Wahyuni, 2017). In her gathering, she said that Reflecting on Rahmah elYunusiyyah's leadership struggle, the potential for future women's leadership must be focused on empowerment. intellectuality to display the desired quality, so that if women's resources are used, then this will become an extraordinary potential for community strength, which will become a reality.

Furthermore, Lindayanti in her research entitled Minangkabau women on the political stage in 2019. In her conclusion, she stated that women's movement figures, both in education and politics, are essentially fighting for women's rights, such as Rohana Kudus, Rusana Said, Saadah Alim, and Rahmah el Yunusijjah (Lindayanti, 2019). Rohana Kudus struggle is in the field of education by establishing a craft school, Amai (Mother) Setia in 191, and also struggling through the mass media. Then, Rasuna Said's political struggle began with activities at the Sarekat Rakyat (SR) as branch secretary, and then joined Soematra Thawalib and Persatoean Moeslimin Indonesia (PERMI) in Bukittinggi in 1930. Saadah Alim is a fighter for the emancipation of Minangkabau. She voiced her thoughts for Minangkabau women to participate in the women's movement in Java and Indonesia. Meanwhile, Rahmah el Yunusiyah is categorized as a modern Muslim, whose thoughts were devoted to reforming Islamic education in Minangkabau. Likewise Wendi Ahmad Wahyudi in his research entitled Minangkabau Women from Ideal-Traditional Conception, Modernization, to Loss of Identity in 2018 (Wendi Ahmad Wahyudi, n.d.). In his conclusion, he said that in the contemporary era, Minangkabau women were nicknamed limpapeh rumah nan gadang which means that many people find themselves in the rumah gadang (the big house). Now Minangkabau women are not only at home who function as wives 
(domestic sector) but also in the business world, education, health, journalism, and various other sectors (public sector). Modern people or adherents of modernity ideologies carry their magic word, freedom, everywhere and to all aspects of life. Spirituality is negated because it is seen as irrational. The development of science should not be limited, except by social ethics, which in fact are also very often violated. Furthermore, Yanuardi Syukur in his research entitled The Rise of Female Ulama in Indonesia: A Gender Perspective in 2018 (Yanuardi Syukur, 2018). In his conclusion he stated that Among the interesting discourses put forward by the Indonesian Women Ulama Congress (KUPI) held in April 2017 in Cirebon, West Java. Women activists and ulama discussed strategic issues concerning Islamic studies, the women's movement, national economic and political empowerment on how women should gain more access and take stronger leadership roles at the national and local levels. Likewise Yuliati in her research entitled Concept of Taman Siswa Women's Education in 2016 (Yulianti, 2016). In her conclusion, she stated that tamansiswa paid special attention to women, this was related to the nature of women as a place for human origin. As a holder of female descent, it is important to pay attention to things since choosing a quality life partner by not neglecting to look at seeds, weight, and weight. And so is Rusli Takunas' research entitled the dynamics of women's education in Islamic history in 2018 (Rusli Takunas, 2018). In his conclusion, he states that this study concludes that in the history of Islam which experienced a period of decline, women were not only limited in going to school but were also marginalized and prohibited from participating in social activities. In the classical and reform era, women and men had equal positions in terms of education and social activities. Finally, we can know that Rahmah Elyunusiyah is a person who is a high achiever, a pioneer of women's emancipation, a fighter, nationalism, and a pioneer who has original thoughts and aspirations and concrete efforts as his patents. This should be noted because it is an ingredient for building a better future, especially for women to increase their dignity, which is still uneven in the Indonesian region. The struggle and sacrifice of rahmah elyunusiyah needs to be continued and continued for the present generation because the problems for women today are no less important than those for women during the life of rahmah elyunusiyah.

\section{CONCLUSIONS}

Rahmah el-Yunusiyah founded Diniyah school Puteri with the background of her goal of wanting women in Indonesia to have the same opportunity as men to study knowledge so that it can be applied in their daily lives.Rahmah el-Yunusiyah is also a woman who is strong in her stance in instilling religious lessons in the educational institution she built, namely Diniyah school daughter. According to him, religious education (Islam) is the basis for the formation of human character, and becomes the essence for other activities, including politics. At the school he started, he tried to keep away from practical political activities. So that students at school focus on learning diligently, diligently and full of enthusiasm. After graduating and graduating from school, only then do students enter society depending on their talents and interests.

\section{ACKNOWLEDGEMENTS}

We express our gratitude and appreciation for the trust that has been given by Universitas Bina Bangsa.

\section{AUTHOR CONTRIBUTION STATEMENTS}


First author had contribution for collecting data in this research. Corresponding author was a corresponding person with editor, from submission until publish for this article. Another authors help to improve this research paper before submit to journal.

\section{REFERENCES}

Abuddin Nata. (2005). Tokoh-Tokoh Pembaharu Pendidikan Islam di Indonesia. Raja Grafindo Persada. Google Scholar

Arief Furchan dan Agus Maimun. (2005). Studi Tokoh Metode Penelitian Mengenai Tokoh. Pustaka Pelajar. Google Scholar

Asni Furoidah. (2019). Tokoh Pendidikan Islam Perempuan Rahmah el-Yunusiyah. Falasifa: Jurnal Studi Keislaman, 10(2). https:// doi.org/10.36835/falasifa.v10i2.194

Anggito, A., \& Setiawan, J. (2018). Metodologi penelitian kualitatif. CV Jejak (Jejak Publisher). Google Scholar

Deliar Noer. (1996). Gerakan Modern Islam di Indonesia 1900 - 1942. LP3ES. Google Scholar

Devi Wahyuni. (2017). Kebijakan kepemimpinan perempuan dalam kependidikan Islam: refleksi atas kepemimpinan RKY Rahmah el-Yunusiyah. Islam Realitas: $\begin{array}{lllll}\text { Journal of Islamic and Sosial } & \text { Studies, }\end{array}$ http:/ / dx.doi.org/10.30983/islam_realitas.v3i1.273

Djunaidatul Munawaroh. (2000). Rahmah el-Yunusiyah: Pelopor Pendidikan Perempuan. PT. Gramedia Pustaka. Google Scholar

Dudung Abdurrahman. (2000). Kilas Balik Pembaharuan dalam Islam. Tsaqafiyyat Jurnal Bahasa, Peradaban Dan Informasi Islam, 1(1), 94. Google Scholar

Gadis Arivia. (2002). Kebijakan Publik Dalam Pendidikan Sebuah Kritik dan Perspektif Gender. Jurnal Perempuan, 23, 91. Google Scholar

Harun Nasution. (1975). Pembaharuan dalam Islam: Sejarah Pemikiran dan Gerakan. Bulan Bintang. Google Scholar

Nasution, H. (2019). Islam ditinjau dari berbagai aspeknya. Google Scholar

Kareel A Steen Brink. (1994). Pesantren Madrasah Sekolah Pendidikan Islam dalam Kurun Waktu Modern. LP3ES. Google Scholar

Lexy J. Moleong. (2018). Metodologi Penelitian Kualitatif. Remaja Rosdakarya. Google Scholar

Lindayanti. (2019). Perempuan minangkabau dalam panggung politik. Mozaik: Jurnal Ilmu-Ilmu Sosial Dan Humaniora, 1(1). Google Scholar

Masyitoh, D., Mustika, R. D., Alfaza, A. S., Hidayatullah, A. F., \& Umar Al Faruq, A. H. (2020). Amin Abdullah dan Paradigma Integrasi Interkoneksi. Attractive: Innovative Education Journal, 2(1), 108-116. Google Scholar

Muhammad al-Habasy (2019) . al- Mar'ah Baina al-Syari'ah wa al-Hayah: Perempuan Ulama di atas Panggung Sejarah: Bagian 1. Exposure Journal on Launching Buku Dan Seminar Ulama Perempuan, 1(4), 4.

Muhammad Azhar. (1996). Fiqh Kontemporer dalam Pandangangan Neomodernisme Islam. Pustaka Pelajar.

Mukhlis, M. (2020). Kritik Konsep Pembaharuan Islam Harun Nasution dalam Islam di Tinjau dari Berbagai Aspeknya. JURNAL MAHASANTRI, 1(1), 48-78. Google Scholar

Novianti, C. (2020). Kilas Balik Sang Pembaharu. Misykah: Jurnal Pendidikan dan Studi Islam, 5(2), 66-72.Google Scholar

Ni'am, S. (2015). Pendidikan Perspektif Gender Di Indonesia (Menimbang dan Menakar Peran Gender dalam Pendidikan). EGALITA, 10(1) 
https:// doi.org/10.18860/egalita.v10i1.4537

Prilia Wulandari. (2017). Perempuan di Sektor Publik Dalam Perspektif Islam (Pandangan Progresif Rahmah el-Yunusiyah Dalam Kepemimpinan sebagai Ulama dan Pelopor Pendidikan Muslimah Indonesia). Jurnal Analisis Gender Dan Agama, 1(1), 1-26.

Pratama, I. P., \& Zulhijra, Z. (2019). Reformasi Pendidikan Islam Di Indonesia. Jurnal PAI Raden Fatah, 1(2), 117-127. Google Scholar

Rohmatun Lukluk Isnaini. (2016). Ulama Perempuan dan Dedikasinya dalam Pendidikan Islam (Telaah pemikiran rahmah el-Yunusiyah). Jurnal Pendidikan Agama Islam, 4(1), 2-16.

Rusli Takunas. (2018). Dinamika pendidikan perempuan dalam sejarah Islam. MUSAWA: Jurnal IAIN Palu,

https://jurnal.iainpalu.ac.id/index.php/msw/article/view/386/268

Saiful Falah. (2014). Parent Power. Republika Penerbit.

Sidi Gazalba. (1996). Pengantar Sejarah Sebagai Ilmu. Bharata.

Sutrisno Ahmad. (n.d.). Usulut Tarbiyah wa Ta'lim Vol. 3. Darussalam Press.

Tim. (1999). Ensiklopedi Islam Bagian 4 NAH-SYA. Ichtiar Baru Van Hoeve.

Wendi Ahmad Wahyudi. (n.d.). Perempuan Minangkabau dari Konsepsi Ideal-Tradisional, Modernisasi, sampai Kehilangan Identitas. Google Scholar

Yanuardi Syukur. (2018). The Rise of Female Ulama in Indonesia: A Gender Perspective. Risea: Review of Islam in Southeast Asia, 1(1). Google Scholar

Y Yuliati, Y. (2018). Konsep Pendidikan Perempuan Taman Siswa. Sejarah dan Budaya: Jurnal Sejarah, Budaya, dan Pengajarannya, 10(1), 114-124.. http:/ / dx.doi.org/10.17977/um020v10i12016p114

Zulmuqim. (2015). transformation of the Minangkabau Islamic education: the study of education thought of Abdul Karim Amrullah, Abdullah Ahmad, and Rahmah elYunusiah. AL-TA'LIM JOURNAL, 22(2), 155-164. https:// doi.org/10.15548/jt.v22i2.139

Copyright Holder :

(C) Rodin, R., \& Huda, M., (2020).

First Publication Right :

(C) IJoASER (International Journal on Advanced Science, Education, and Religion)

This article is under:

CC BY SA 